\title{
Size-dependent antioxidative activity of platinum nanoparticles
}

\author{
Hidekazu Nakanishi ${ }^{1 *}$, Takeki Hamasaki ${ }^{2}$, Tomoya Kinjo ${ }^{1}$, Kiichiro Teruya ${ }^{1,2}$, Shigeru Kabayama ${ }^{3}$, \\ Sanetaka Shirahata ${ }^{1,2}$ \\ From 23rd European Society for Animal Cell Technology (ESACT) Meeting: Better Cells for Better Health \\ Lille, France. 23-26 June 2013
}

\section{Background}

So far, most of studies on nanometer-sized metal particles have focused on biological safety and potential hazards. However, anti-oxidative activity of noble metal nanoparticles (NPs) attracts much attention, recently. Platinum nanoparticles (Pt NPs) are one of the most important noble metals in nanotechnology because $\mathrm{Pt}$ NPs have negative surface potential from negative charges and are stably suspended from an electric repulsion between the same charged particles [1]. We previously reported that Pt NPs of 2-3 nm sizes scavenged reactive oxygen species (ROS) such as superoxide anion radical, hydrogen peroxide and hydroxyl radical in vitro [2]. Here, we report the cytotoxicity and size-dependent antioxidative activity of Pt NPs on rat skeletal muscle cell line, L6.

\section{Materials and methods}

Pt NPs were synthesized by a modified citrate reduction method of Hydrogen hexachloroplatinate (IV). Particle size and concentrations of Pt NPs were determined by a transmittance electron microscope (TEM) and ICP-MS, respectively. To find the toxic effect of Pt NPs rat myoblast L6 cells were pre-cultured for 24 hours in culture medium with a $10^{-3}$ to $10 \mathrm{mg} / \mathrm{l}$ of $\mathrm{Pt}$ NPs and cell viability was determined by WST-1 assay. To investigate the anti-oxidative effect of Pt NPs on L6 cells, the relative amount of intracellular $\mathrm{H}_{2} \mathrm{O}_{2}$ was measured with a Bes- $\mathrm{H}_{2} \mathrm{O}_{2}-\mathrm{AC}$ florescent probe, which is designed to detect intracellular $\mathrm{H}_{2} \mathrm{O}_{2}$ specifically [3]. The intracellular ROS levels when treated with $1 \mathrm{mg} / \mathrm{l}$ of Pt NPs for 2 hours were measured using IN Cell Analyzer 1000.

\section{Results and conclusions}

The particle sizes we synthesized were determined to $1-2 \mathrm{~nm}, 2-3 \mathrm{~nm}$ and $4 \mathrm{~nm}$ respectively (data not shown). Cytotoxicity of Pt NPs of these sizes was not observed at a concentration below $10 \mathrm{mg} / \mathrm{l}$ (data not shown). Intracellular ROS levels are thought to result from a primary response to internalized NPs leading to decreased cell viability [4]. Thus, the suppression of excess ROS is of prime importance for cell survival. The intracellular ROS levels were decreased significantly by the whole sizes of Pt NPs treatment and 2-3 nm of Pt NPs scavenged the ROS most efficiently (Figure 1). The relative fluorescence level treated with 2-3 nm of Pt NPs decreased significantly to about $60 \%(* * \%) \mathrm{P}<0.001)$ compared with that of non-treated cells. Smaller NPs should be more taken up by the cells efficiently and might more scavenge ROS effectively [5]. However, the Pt NPs of 1-2 nm less scavenged the intracellular ROS than that of $2-3 \mathrm{~nm}$. The one reason might be that 1-2 nm of Pt NPs is rather too small to activate intracellular anti-oxidant defense pathways than 2-3 nm of Pt NPs because of their less cytotoxicity. However, we have no data to show. Therefore, we have to make more effort to investigate the relationship between the sizes of Pt NPs and ROS scavenging activity.

Our results suggest Pt NPs of 2-3 nm sizes have no cytotoxity below $10 \mathrm{mg} / \mathrm{l}$ and are useful materials to scavenge ROS. In this regard Pt NPs are expected as redox regulation factors for suppression of various ROS-related diseases. 


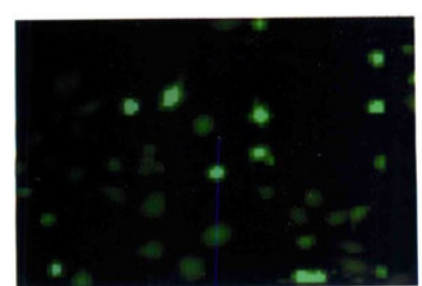

Control

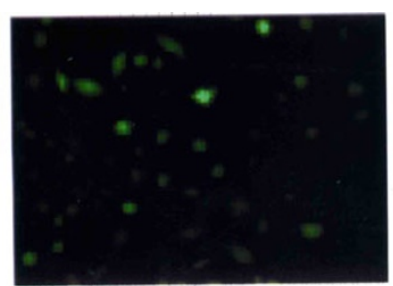

Pt NPs 1-2 nm

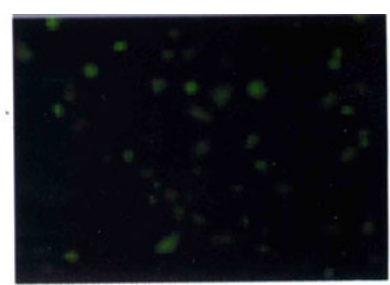

Pt NPs 2-3 nm

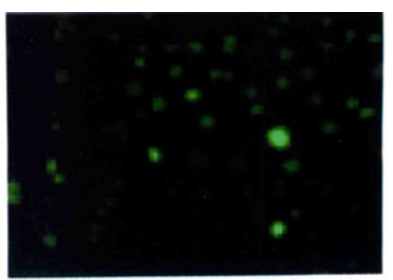

Pt NPs $4 \mathrm{~nm}$

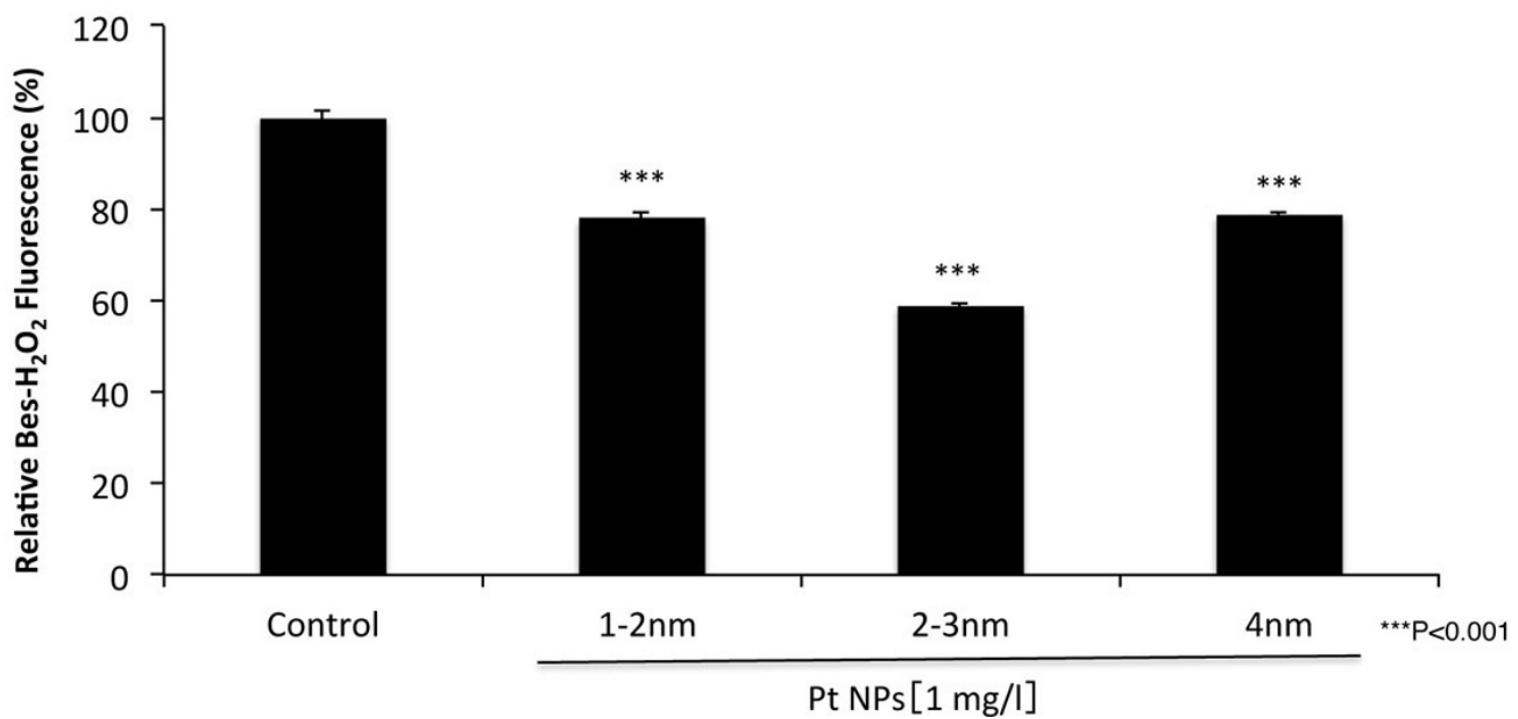

Figure 1 The scavenging effect of several sized Pt NPs on intracellular hydrogen peroxide in L6 cells. Asterisks donate significant difference from the untreated control cells. (**P $<0.001)$.

\section{Authors' details}

'Division of Life Engineering, Graduate School of Systems Life Sciences, Kyushu University, Fukuoka 812-0053, Japan. ${ }^{2}$ Department of Bioscience and Biotechnology, Faculty of Agriculture, Kyushu University, Fukuoka 812-0053, Japan. ${ }^{3}$ Nihon Trim Co. Ltd, Osaka 531-0076, Japan.

Published: 4 December 2013

\section{References}

1. Aiuchi T, Nakajo S, Nakaya K: Reducing activity of colloidal platinum nanoparticles for hydrogen peroxide, 2,2-diphenyl-1-picrylhydrazyl radical and 2,6-dichlorophenol indophenol. Biol Pharm Bull 2004, 27:736-738.

2. Hamasaki T, Kashiwagi T, Imada T, Nakamichi N, Aramaki S, Toh K, Morisawa S, Shimakoshi H, Hisaeda Y, Shirahata S: Kinetic analysis of superoxide anion radical-scavenging and hydroxyl radical-scavenging activities of platinum nanoparticles. Langmuir 2008, 24:7354-7364.

3. Maeda H, Fukuyasu Y, Yoshida S, Fukuda K, Saeki K, Matsuno H, Yamauchi Y, Yoshida K, Hirata K, Miyamoto K: Fluorescent probes for hydrogen peroxide based on a non-oxidative mechanism. Angew Chem Int Ed Engl 2004, 43:2389-2391.

4. Long TC, Tajuba J, Sama P, Saleh N, Swartz C, Parker J, Hester S, Lowry GV, Veronesi $B$ : Nanosize titanium dioxide stimulates reactive oxygen species in brain microglia and damages neurons in vitro. Environ Health Perspect 2007, 115:1631-1637.

5. Hirn S, Semmler-Behnke M, Schleh C, Wenk A, Lipka J, Schäffler M, Takenaka S, Möller W, Schmid G, Simon U, Kreyling WG: Particle sizedependent and surface charge-dependent biodistribution of gold nanoparticles after intravenous administration. Eur J Pharm Biopharm 2011, 77:407-416.

\section{doi:10.1186/1753-6561-7-S6-P41}

Cite this article as: Nakanishi et al: Size-dependent antioxidative activity of platinum nanoparticles. BMC Proceedings 2013 7(Suppl 6):P41.

\section{Submit your next manuscript to BioMed Central and take full advantage of:}

- Convenient online submission

- Thorough peer review

- No space constraints or color figure charges

- Immediate publication on acceptance

- Inclusion in PubMed, CAS, Scopus and Google Scholar

- Research which is freely available for redistribution
Biomed Central 